\title{
Serological and Molecular Characterisation of Cucumber mosaic virus Infecting Lagenaria siceraria L. in Adim, Biase L.G.A., Cross River State, Nigeria
}

\author{
O. I. Eyong ${ }^{1}$, A. T. Owolabi ${ }^{2}$, A. A. J. Mofunanya ${ }^{2^{*}}$ and E. E. Ekpiken ${ }^{3}$ \\ ${ }^{1}$ Department of Forestry and Wildlife Management, Cross River State \\ University of Technology, Calabar, Nigeria. \\ ${ }^{2}$ Department of Botany, University of Calabar, Calabar, Nigeria. \\ ${ }^{3}$ Department of Plant and Biotechnology, Cross River State University of Technology, \\ Calabar, Nigeria.
}

\section{Authors' contributions}

This work was carried out in collaboration among all authors. Author ATO designed the study and wrote the protocol. Author OIE handled data collection, performed the statistical analysis and wrote the first draft of the manuscript. Author AAJM managed the literature searches. Author EEE managed the analyses of the study. All authors read and approved the final manuscript.

Article Information

DOI: $10.9734 / A R R B / 2020 / v 35 i 430211$

Editor(s):

(1) Dr. Oluyomi A. Sowemimo, Obafemi Awolowo University, Ile-Ife, Osun State, Nigeria.

Reviewers:

(1) Moataz Eliw, Al-Azhar University, Egypt. (2) Ferreira, Luiz Leonardo, Universidade Estadual da Paraiba, Brazil. Complete Peer review History: http://www.sdiarticle4.com/review-history/54366

Original Research Article

Received 29 November 2019

Accepted 03 February 2020

Published 02 June 2020

\begin{abstract}
Cucumber mosaic virus (CMV) is one of the most important viral pathogens infecting a wide range of plant species in Nigeria. Mosaic and mottle symptoms were observed on Lagenaria siceraria L. in Adim Southern-Nigeria in 2018 and the infected leaves collected for investigation. This research was aimed at characterising the virus responsible for this infection with a view to identifying it. Antigen coated plate (ACP) enzyme linked-immunosorbent assay (ELISA) and gene sequencing were employed methods in the characterisation process. The Amplified Complementary Deoxyribonucleic Acid (cDNA) was cloned and the nucleotide sequence was determined. Result of serology revealed that the virus belonged to the genus Cucumovirus while the gene sequence
\end{abstract}


obtained when compared to known virus sequences present in the GenBank using the Basic Local Alignment Search Tool (BLAST) program available at National Centre for Biotechnology Information (NCBI) revealed $97 \%$ sequence homologue with Cucumber mosaic virus confirming it as Cucumber mosaic virus. This is the first report of CMV infecting $L$. siceraria in Nigeria. I recommend further studies on insect and host range test of this virus be carried on.

Keywords: Cucurbitaceae; RT-PCR; Cucumovirus; Amplicon; Potyvirus.

\section{INTRODUCTION}

The Family Cucurbitaceae comprises of about 95 genera and 965 species. Lagenaria siceraria $\mathrm{L}$. commonly called bottle gourd is one of the important vegetable crops in this family, it is one of humankind's first domesticated plants, providing food, medicine and a wide variety of utensils and musical instruments [1].

Lagenaria siceraria has been reported to be threatened by diseases of fungal, bacterial and viral origin [2] and pests, such as the pumpkin caterpillars (Diaphania spp.) and the melon fly (Bactrocera cucurbitae Coquillet). These have constituted serious constraints to the cultivation of this plant [3-6]. Aphids, whiteflies and thrips can become serious limitations to the production of $L$. siceraria through the extensive damage they provoke and also through the transmission of viral disease [7-9].

Plant viruses are ranked the most common causal agents of diseases infecting $L$. siceraria worldwide [10]. Cucumber mosaic virus is the type member of the genus Cucumovirus (family Bromoviridae) reported to infect $L$. siceraria. The size of CMV genome is approximately $8 \mathrm{~kb}$ consisting of three linear positive-sense single stranded RNA molecules [11] which are packaged in separate icosahedral virions. The virus is mechanically transmissible and also by aphids in a non-persistent manner [12] and is divided into two subgroups (I and II) based on nucleotide sequence identity and serological properties and is reported to infect over 1,000 species in more than 85 botanical families [13]. Since CMV has an extensive host range, there are numerous records of susceptible species causing severe economic losses. Therefore, mosaic and mottle symptoms observed on this plant are suspected to be caused by CMV (Plate 1).

Several viruses infecting cucurbits have been characterized and identified in different parts of Nigeria. [14] reported infection of cucurbits in Northern Nigeria, [15] reported infection of cucumber by Potato ring spot virus (PRSV) and infection of Cucurbita moschata by Moroccan watermelon mosaic virus (MWMV) in Calabar Southern Nigeria, [16,17] characterised Yam mosaic virus (YMV) and Tobacco mosaic virus (TMV) infecting cucurbits in Northern Nigeria. [18] provided a checklist of viruses prevalent in South West Nigeria. However, studies regarding virus infecting $L$. siceraria are lacking in Nigeria. This study was aimed at characterising the virus responsible for the infection of $L$. siceraria with a view to identifying it.

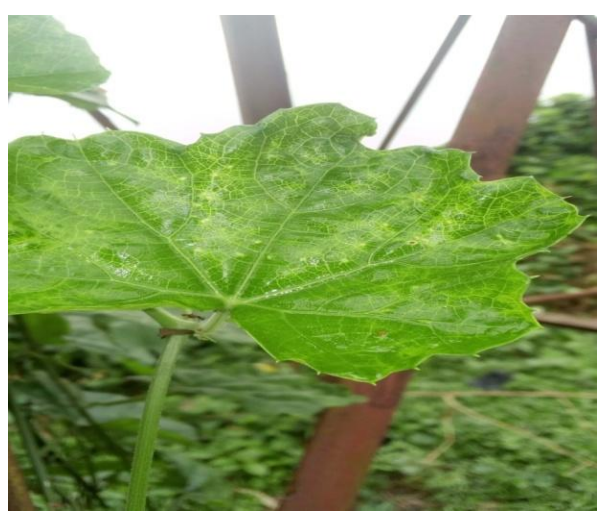

Plate 1. Mosaic and mottle symptoms on Lageneria sceseraria

\section{MATERIALS AND METHODS}

\subsection{Source, Isolation and Maintenance of Virus Isolate}

Infected leaf sample showing symptoms of mosaic and mottle was isolated from $L$. siceraria in Adim, Biase Local Government Area of Cross River State, Nigeria in 2018 and maintained through mechanical inoculation on carborundum (600 mesh) dusted leaves of Cucumeropsis mannii and were thereafter used as source of inoculum.

\subsection{Preparation of Virus Inoculum and Maintenance}

Virus inoculums were prepared by triturating symptomatic virus infected leaf tissues of $L$. 
siceraria in pre-sterilized cold pestle and mortar in the inoculation buffer and maintained on young seedlings of Cucumeropsis mannii in the screen house of the University of Calabar, Calabar, Nigeria.

\subsection{Serological Tests}

Antigen coated plate enzyme linked immunosorbent assay (ACP-ELISA) as described by [19] was used to determine the genus to which the virus isolate belong to. The symptomatic leaf sample of $L$. siceraria of $0.1 \mathrm{~g}$ was triturated in $1 \mathrm{ml}$ of coating buffer $(0.015 \mathrm{M}$ $\mathrm{Na}_{2} \mathrm{Co}_{3}+0.0349 \mathrm{M} \mathrm{NaHCO}{ }_{3}+\mathrm{dH}_{2} \mathrm{O}$ ) and dispensed into ELISA plates. After incubation at $37^{\circ} \mathrm{C}$ for 1 hour the plate was washed 3 times with phosphate buffer solution (PBS-Tween) for 3 min between each wash. Cross adsorption was made by grinding $1 \mathrm{~g}$ of healthy plant sample in $20 \mathrm{ml}$ of conjugate buffer ( $1 / 2$ PBS $+0.05 \%$ Tween $20+0.02 \%$ egg albumin $+0.2 \%$ PVP). Antisera to CMV and the universal potyvirus antiserum were diluted at 1:3000 in the adsorption solution and $100 \mu \mathrm{L}$ of each antiserum polyclonal antisera were added to the wells of the ELISA plates and again incubated at $37^{\circ} \mathrm{C}$ for 1 hour. The ELISA plates were then washed 3 times with phosphate buffer solution (PBS-Tween). One hundred $\mu \mathrm{L}$ of protein, Aalkaline phosphatase conjugate diluted in the ratio $1: 15000$ in conjugate buffer $(1 / 2$ PBS + $0.05 \%$ Tween $20+0.02 \%$ egg albumin $+0.2 \%$ PVP $+0.02 \mathrm{~g} \mathrm{NaNO}_{3}$ ) was added per well and the plates incubated at $37^{\circ} \mathrm{C}$ for 1 hour. The plates were again washed 3 times with PBS-T. One hundred- $\mu \mathrm{l}$ of $0.001 \mathrm{~g} \cdot \mathrm{ml}^{-1}$ of $p$-nitrophenyl phosphate substrate in substrate buffer $(97 \mathrm{ml}$ diethanolamine $+800 \mathrm{ml} \mathrm{H}_{2} \mathrm{O}+0.2 \mathrm{~g} \mathrm{NaNO}_{3}$ and $\mathrm{HCl}$ to give $\mathrm{pH}$ 9.8) was added per well and incubated at room temperature for 1 hour. For all incubations, plates were covered with ELISA cover plates to avoid edge effects and to maintain uniform temperature. Healthy plant samples were used as controls. Absorbance $\left(\mathrm{A}_{405 \mathrm{~nm}}\right)$ was measured after $1 \mathrm{~h}$ of incubation, using an ELISA plate reader (Micro Read 1000 ELISA Plate Analyser, U.S.A). The samples were considered positive when the ELISA reading was at least twice the reading for the healthy control [19].

\subsection{RNA Extraction from Infected Leaf Samples}

Total RNA was isolated from the infected leaf sample of $L$. siceraria using a cetyltrimethylammonium bromide (CTAB) protocol as described by [20]. One hundred milligram of the infected leaf sample was grounded in sterile mortar and pestle using $1 \mathrm{ml}$ extraction buffer (100 mM Tris- $\mathrm{HCl}, \mathrm{pH} 8.0 ; 1.4$ M NaCl; 20 mM EDTA; 2\% CTAB) (hexadecetyltrimethylammonium bromide); and $0.4 \% \quad \beta$ - mercaptoethanol, added just before used. The sap was poured into a new $1.5 \mathrm{ml}$ Eppendorf tube. The tubes were vortexed briefly, incubated in a $60^{\circ} \mathrm{C}$ water bath for 10 minutes, and then allowed to cool to room temperature. Then $0.75 \mathrm{ml}$ of phenol chloroform isoamyl $(25: 24: 1)$ was added to each tube containing the sap. Each tube was vortexed vigorously to form an emulsion and then centrifuge at maximum speed of $12000 \mathrm{rcf}$ for 10 minutes.

The supernatant was then transferred to a clean $1.5 \mathrm{ml}$ tube. Three hundred of cold isopropanol was added to the supernatant to precipitate the nucleic acid (RNA) and mixture kept at $-80^{\circ} \mathrm{C}$ for 10 minutes. The mixture was centrifuge at $12,000 \mathrm{rcf}$ for $10 \mathrm{~min}$ to precipitate the nucleic acid. The supernatant was discarded and the nucleic acid pellet washed in $500 \mu \mathrm{l}$ of $70 \%$ ethanol and centrifuge at 12,000 rcf for $5-10$ minutes. The ethanol was decanted and the resultant nucleic acid pellet was air-dried at room temperature. Nucleic acid pellet was then resuspended in $50 \mu \mathrm{l}$ sterile distilled water and used as a template source for RT-PCR. Nucleic acid extracts from the leaves of healthy plants were used as negative control, whereas nucleic acid extracts from infected leaves samples with known potyvirus infection were used as positive control.

\subsection{Reverse Transcript Polymerase Chain Reaction (RT-PCR)}

Virus-specific cDNA fragment was amplified from total nucleic acid derived from the infected leave sample by a RT-PCR method as described by [21]. RT-PCR was performed using the CMV primer Forward 5'GGIVVIGTIGGIWSIAARTCIAC3', Reverse 5 ACICCRTTYTCDATDATRTTIGTIGC 3 as described by [22]. The RT-PCR reaction mixture $(50 \mu \mathrm{l})$ consisted of I $\mu \mathrm{l}$ each of CICP 5 and $\mathrm{CICP}$ 3', $5 x$ Go Taq green buffer (10.0 $\mu \mathrm{l}), \mathrm{MgCl}_{2}$ (3.0), dNTPs $(1.0 \mu \mathrm{l})$, Reverse transcriptase $(0.24 \mu \mathrm{l})$, Taq DNA polymerase (Promega) $(0.24 \mu \mathrm{l})$, sterile distilled water $(30.52 \mu \mathrm{l})$, nucleic acid (1:10 dilution) $(3.0 \mu \mathrm{l})$.

Amplifications were carried out in a GeneAmp 9700 PCR system thermalcycler (Applied 
Biosystem Incorporated, USA) using the following thermocyclic conditions; $42^{\circ} \mathrm{C}$ for 30 minutes for reverse transcription, $94^{\circ} \mathrm{C}$ for 3 minutes for initial denaturing, followed by 40 cycles of denaturing at $94^{\circ} \mathrm{C}$ for $30 \mathrm{~s}$, an annealing step at $40^{\circ} \mathrm{C}$ for $30 \mathrm{~s}$, an extension at $68^{\circ} \mathrm{C}$ for 1 minute and a final extension at $72^{\circ} \mathrm{C}$ for 10 minutes ended the RT-PCR reaction. The PCR reaction products were separated on $1.5 \%$ agarose gel, subsequently stained with ethidium bromide, visualized in UV light and photographed RT-PCR assay produced a PCR amplicon of expected size (approximately $500 \mathrm{bp}$ ).

\subsection{Amplicon Purification Sequencing}

and

The RT-PCR amplicon was purified, 95\% ethanol was added to $40 \mu \mathrm{l}$ of the amplicon in a new $1500 \mu \mathrm{l}$ Eppendorf tube and solution kept in $-80^{\circ}$ $\mathrm{C}$ for 10 minutes. The tube was centrifuged at maximum speed for 10 minutes and the supernatant discarded. Five hundred of $70 \%$ ethanol was added and centrifuge at maximum speed for 5 minutes, the supernatant was discarded and the tube left in room temperature to dry the purified cDNA after which the purified product was dissolved in $30 \mu \mathrm{l}$ of sterile distil water. The product was then sent to International Institute for Tropical Agriculture (IITA) bioscience laboratory for sequencing.

\subsection{Sequence Analysis}

The sequences were compared to known viral sequence using BLAST program available at National Centre for Biotechnology Information (NCBI) (http://www.ncbi.nlm.nih.gov/BLAST/). Sequence identities were calculated from the "sequence identity matrix" option in MEGA 6 window software.

\section{RESULTS}

\subsection{Antigen Coated Plate (ACP) Testing against Potyvirus and Cucumovirus antisera}

The results obtained from this test revealed that the virus isolate reacted positively against the CMV antiserum, there was negative reaction against the universal potyvirus antiserum (Table 1).

\subsection{Gene Sequence and Sequence Alignment}

Fig. 1 represents nucleotide sequence of the virus isolated from Lagenaria siceraria.

Results as shown in Fig. 2 revealed gene alignment of the virus isolate showing $97 \%$ sequence homologue with Cucumber mosaic virus, Sequence ID: MG021460.1. 97\%.

Table 1. Antigen Coated Plate (ACP) Enzyme Linked Immunosorbent Assay (ELISA) for detection of Cucumber mosaic virus (CMV) and Potyviruses

\begin{tabular}{|c|c|c|c|}
\hline \multirow[t]{2}{*}{ Samples } & \multirow[t]{2}{*}{ Location } & \multicolumn{2}{|c|}{$\begin{array}{l}\text { OD reading at } A_{405} \mathrm{~nm} \text { against } \\
\text { Virus Polyclonal Antibodies }\end{array}$} \\
\hline & & CMV & Potyvirus \\
\hline Lagenaria siceraria virus isolate & Adim & $0.894^{*}$ & 0.562 \\
\hline Healthy Control & & 0.326 & 0.405 \\
\hline Infected Control & & 2.687 & 1.894 \\
\hline
\end{tabular}

AgATAAAGGAATGGGGGACTTCGACGGTTTGTAGATTACCGCCAACTCAGGTCCCGCCTAAAGGAGGG
ACTCCGCTAAGCACGAGCAATACATTCGGCGATTAAGTCGCCGCCTAACATACCACAATACTCATAGC
GGAAGGTGACCTTATGTCTAGTCAAAGCGACAAGACAATAAGAAAATTTCTTAAATAGGTCACACTTT
GTGCTCTTTAATCTTACCAAAGTAACGTGGTCCTCAGAAATACCCTGGGACTCATGCACAGTTTTGAT
TCTTTCGTTCCAGAAAGTCTTCGGTAAGTTCATCTCTTTCGCCCTTGAAATTAGTGAAGCTTTATCAG
CTTGCGTCATCGTGACATAAAACCTAGAAGAATCCAGATCAACCATAGTCACACTTTCGACAGCACGA

GATGTCACAGATCTCTTCACTATAGATTGAGAAACCCATCTGGTGTATTTTGAGTGGGTTCCTTTCGG

AAGGGCCTTCGTAGCCATTAAACGCCACCAAGCGGAGCCATTA

Fig. 1. Gene sequence of virus isolated from Lagenaria siceraria 


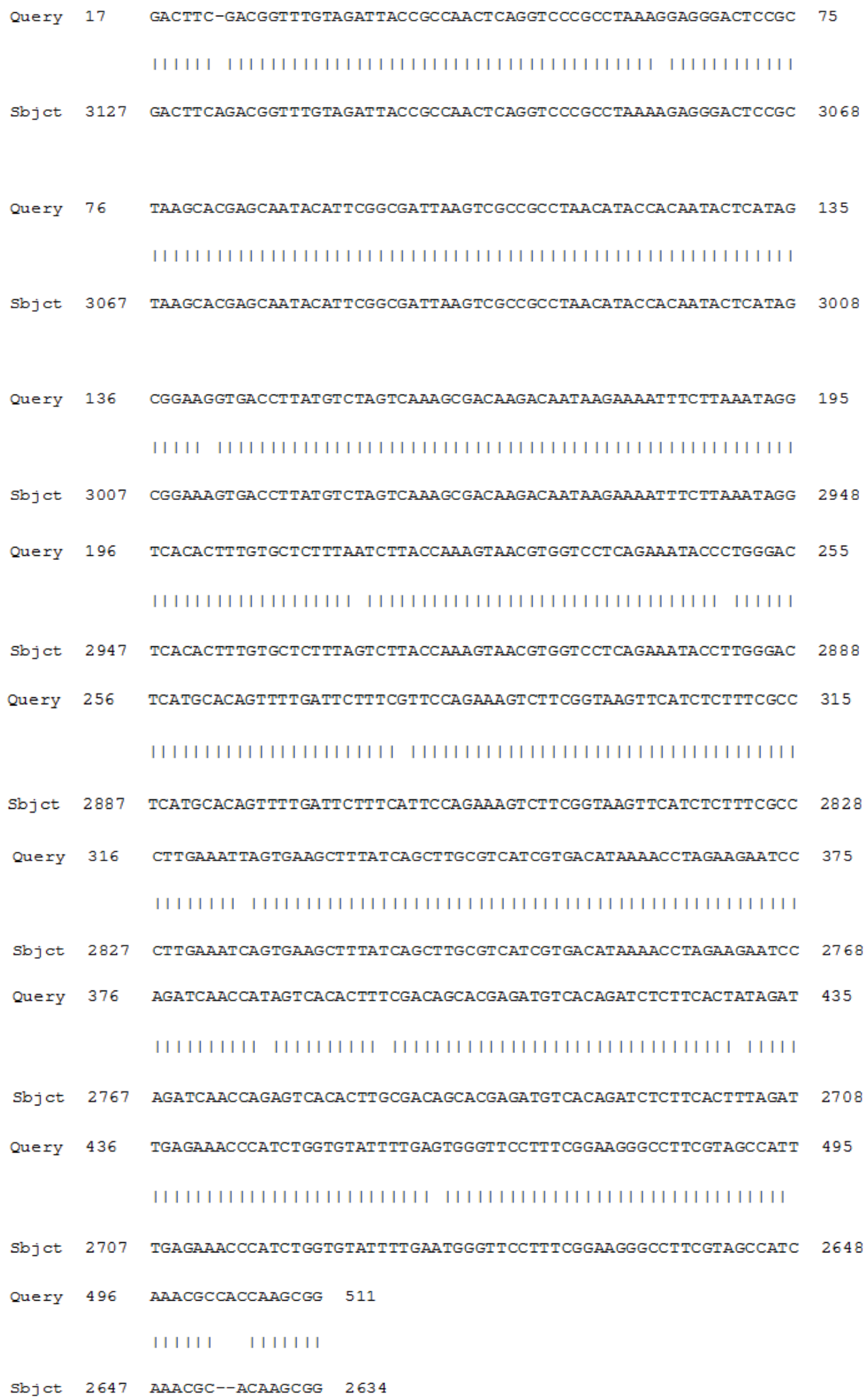

Fig. 2. Gene alignment of the virus sequence showing $97 \%$ sequence identity with Cucumber mosaic virus isolate, Sequence ID: MG021460.1 
Query stands for virus sequence of Lagenaria siceraria while Subject is the Cucumber mosaic virus available at NCBI database.

\section{DISCUSSION}

\subsection{Serological Tests}

ACP-ELISA has been employed in the detection and identification of plant viruses into the genus taxon [23-29]. The detection of the virus isolate in this study by the cucumovirus antiserum suggests it belongs to the genus Cucumovirus.

\subsection{Gene Sequence and Sequence Alignment}

Gene sequencing as tool for virus identification and characterization has become the ultimate in recent times [30-41].

A virus identity will become unassailable if the degree of homologue of it sequence is established after comparison with sequences of previously characterised members of the genus to which the virus in question belongs.

It has been suggested by $[42,40,43]$ that virus sequence with less than approximately $76 \%$ sequence identity should be regarded as belonging to different species while isolates with $76-89 \%$ sequence identity should be considered as virus of the same strains and sequence presenting $90-100 \%$ sequence identity should be regarded as same virus.

The virus isolate in this study had sequence homologue of $97 \%$ with CMV which is above $90 \%$ and should therefore be considered as CMV. This is the first report of Cucumber mosaic virus infecting $L$. siceraria in Nigeria.

\section{CONCLUSION}

In conclusion, the virus under study was serologically confirmed to be a Cucumovirus and molecularly identified to be Cucumber mosaic virus. This is the first report of CMV in Nigeria.

\section{COMPETING INTERESTS}

Authors have declared that no competing interests exist.

\section{REFERENCES}

1. Decker-Walters DS, Wilkins-Ellert $M$, Chung SM, Staub JE. Discovery and genetic assessment of wild bottle gourd [Lagenaria siceraria (Mol.) Standley, Cucurbitaceae] from Zimbabwe. Economic Botany. 2004;58:501-508.

2. Sitterly WR. Breeding for disease resistance in cucurbits. Annual Review of Phytopathology. 1972;10: 471-490.

3. Peter C, David BV. Population dynamics of the pumpkin caterpillar, Diaphania indica (Saunders) (Lepidoptera: Pyralidae). Tropical Pest Management. 1991;37:7579.

4. Duyck PF, David P, Quilici S. A review of relationships between interspecific competition and invasions in fruit flies (Diptera tephritidae). Ecological Entomology. 2004; 29:511-520.

5. Dhillon MK, Singh R, Naresh JS, Sharma HC. The melon fruit fly, Bactrocera cucurbitae: A review of its biology and management. Journal of Insect Science. 2005;5:1-16.

6. Hans Petersen HN, McSorley R, Liburd $\mathrm{OE}$. The impact of intercropping squash with non-crop vegetation borders on the above-ground arthropod community. Florida Entomologist. 2010;93:590-608.

7. Brown JK, Frohlich DR, Rosell RC. The sweet potato or silverleaf whiteflies: biotypes of Bemisia tabaci or a species complex? Annual Review of Entomology. 1995;40:511-34.

8. Morse JG, Hoddle MS. Invasion biology of thrips. Annual Review of Entomology. 2006;51:67-89.

9. Powell G, Tosh CR, Hardie J. Host plant selection by aphids: Behavioural, evolutionary and applied perspectives. Annual Review of Entomology. 2006;51: 309-330.

10. Provvidenti R. Diseases caused by viruses. Compendium of cucurbit disease. American Phytopathology Society, St Paul, Minnesota, U.S.A; 1996.

11. Bujarski J, Figlerowicz M, Gallitelli D, Roossinck MJ., Scott SW. Bromoviridae. Virus taxonomy: Ninth report of the international committee on taxonomy of viruses. The Amsterdam, Netherlands. Elsevier/Academic Press. 2012;965-976.

12. Nault LR. Arthropod transmission of plant viruses: A new synthesis. Annals of the Entomological Society of America. 1997; 90:521-541.

13. Hull R. Matthews' Plant Virology. Elsevier Academic Press, San Diego, USA; 2002. 
14. Atiri GI. An isolate of Cucumber mosaic virus from fluted pumpkin in Nigeria. Journal of Phytopathology. 1985;3:4-5.

15. Owolabi AT, Rabenstein F, Ehrig F. A strain of Papaya ringspot virus naturally infecting cucumber (Cucumis sativus L.) in Calabar, South Eastern Nigeria. Nigerian Journal of Botany. 2008;21(1):97108.

16. Owolabi AT, Rabenstein F, Taiwo MA, Ehrigh F, Maiss E. Characterization and identification of a potyvirus causing mosaic disease of Cucurbita moschata Duch Ex. Poir in Calabar, South East Nigeria. International Journal of Plant Pathology. 2011;2(4):165-176.

17. Alegbejo MD, Asala S, Kashina BD, Banwo O, Shinggu CP. Viruses in weeds in Dioscorea yam fields in Nigeria. African Crop Science Journal. 2014;22:109-115.

18. Ayo-John El, Hughes JD. Identification of Cucumber mosaic virus infecting Musa spp. and vegetable crops in Nigeria. International Journal of Virology. 2014;10: 204-210.

19. Kumar. Methods for the diagnosis of plant virus disease. Laboratory manual, IITA Ibadan, Nigeria; 2009.

20. Abarshi MM, Mohammed IU, Wasswa P, Hillocks RJ, Holt J, Legg JP, Seal SE, Maruthi MN. Optimization of diagnostic RTPCR protocols and sampling procedures for the reliable and cost-effective detection of Cassava brown streak virus. Journal of Virology Methods. 2010;163(2):353-359.

21. Pappu S, Brand R, Pappu H, Rybicki E, Gough K, Frenkel M, Niblett C. A polymerase chain reaction method adapted for selective amplification and cloning of 3 sequence of potyviral genomes: application to Dasheen mosaic virus. Journal of Virological Methods. 1993; 41:9-20.

22. Ha C, Coombs S, Dale J. Design and application of two novel degenerate primer pairs for the detection and complete genomic characterisation of potyvirus. Archives of Virology. 2008;153:245-260.

23. Somowiyarjo S, Sako N, Nonaka F. Dotimmunobinding assay for Zucchini Yellow Mosaic Virus using polyclonal and monoclonal antibodies. Annals of the Phytopathological Society of Japan. 1989; 55:56-63.

24. Malaurie B, Trouslot MF, Berthaud J, Bousalem M, Pinel A, Dubern J. Mediumterm and long-term in vitro conservation and safe international exchange of yam (Dioscorea spp.) germplasm. Electronic Journal of Biotechnology. 1998;1(3):103117.

25. Cardoso FH, Armada A, Fonseca AM, Santos MT, Sequeira J, Clemente A, Sequeira O, Novo C. Sequences of the Ntermini of coat proteins of portuguese Zucchini yellow mosaic virus isolates and of an epitope recognized by a monoclonal antibody. Journal of Plant Pathology. 2005; 87:229-232.

26. Shang $H$, Xie $Y$, Zhou $X$, Qian $Y$, Wu J. Monoclonal antibody-based serological methods for detection of Cucumber green mottle mosaic virus. Virology Journal. 2011;8:228.

27. Wulandari DR, Ermayanti TM. Detection of Potyvirus using RT-PCR and ACP-ELISA of Dioscorea species and in vitro shoot multiplication of the virus free plants. Annales Bogoriences. 2011;15(2):56-78.

28. Wu JX, Ni YQ, Liu H, Ding $M$, Zhou XP. Monoclonal antibody-based serological assays and immunocapture RT-PCR for detecting Rice dwarf virus in field rice plants and leafhopper vectors. Journal of Virological Methods. 2014;195:134-140.

29. Zhe C. Zhang M. Zhou X. Wu J. Development and detection application of monoclonal antibodies against Zucchini yellow mosaic virus. Journal of Integrative Agriculture. 2017;16(1):115-124.

30. Ali A, Natsuaki T, Okuda S. Identification and molecular characterization of viruses infecting cucurbits in Oklahoma, USA. Journal of Phytopathology. 2004;152:677682.

31. Daryono B, Somowiyarjo S, Natsuaki T. Biological and molecular characterization of melon-infecting Kyuri green mottle Mosaic virus in Indonesia. Journal of Phytopathology. 2005;153:588-595.

32. Helaly HS, Ahmed AA, Awad MA, Soliman AM. Biological and molecular characterization of potato infecting Alfalfa mosaic virus in Egypt. International Journal of Virology. 2012;8:106-113.

33. Hakan F. Occurrence of Alfalfa mosaic virus (AMV). Diseases on cucumber crops in Northern Cyprus. Acta Horticulturae. 2012;960:341-346.

34. Jain RK, Pappu SS, Varma A, Ram RD. Molecular characterization of Papaya ringspot potyvirus isolates from India. Annual of Applied Biology. 2008;132:413425. 
35. Yakoubi S, Desbiez C, Fakhfakh H, WipfScheibel C, Marrakchi $M$, Lecoq $H$. Biological characterization and complete nucleotide sequence of a Tunisian isolate of Moroccan watermelon mosaic virus. Archives of Virology. 2008;153:117125.

36. Muharrem A, Cecile D, Asime FC. Characterization of an emerging isolate of Watermelon mosaic virus in Turkey. International Journal of Agriculture \& Biology. 2015;17(1):211-215.

37. Lecoq H, Jane R. Zucchini yellow mosaic virus. Plant Patholology Journal. 2001;46: 809-829.

38. Desbiez C, Lecoq H. Zucchini yellow mosaic virus. Plant Pathology. 2012;109: 76-82.

39. Mokaye A. Dtection of plant viruses in natural environment by using RNA sequencing. 2015;1236:89-98.
40. King AM, Lefkowitz E, Adams MJ, Carstens EB. Virus taxonomy: $9^{\text {th }}$ report of the international committee on taxonomy of viruses. Elsevier Academic Press, San Diego, USA; 2011.

41. Usher L, Sivparsad B, Gubba A. Isolation, identification and molecular characterisation of an isolate of Watermelon mosaic virus 2 occurring in KwaZulu-Natal, South Africa. International Journal of Virology. 2012;18:10-17.

42. Shukla DD, Ward CW, Brunt AA. The Potyviridae. CAB International, Wallingford; 1994.

43. Frenkle MJ, Ward CW, Shukla DD. The use of 3' non-coding nucleotide sequences in the taxonomy of potyviruses: Application to watermelon mosaic virus 2 and soybean mosaic virus- $\mathrm{N}$. Journal of General Virology. 1989;70:27752783.

(c) 2020 Eyong et al.; This is an Open Access article distributed under the terms of the Creative Commons Attribution License (http://creativecommons.org/licenses/by/4.0), which permits unrestricted use, distribution, and reproduction in any medium, provided the original work is properly cited.

Peer-review history:

The peer review history for this paper can be accessed here: http://www.sdiarticle4.com/review-history/54366 